\title{
In vivo Analgesic, Antipyretic and Anti-inflammatory Activities of Ethanol Extract of Pericampylus glaucus in Experimental Animals
}

(Aktiviti Analgesik, Antipiretik dan Anti-Radang secara in vivo Ekstrak Etanol daripada Pericampylus glaucus pada Haiwan Uji Kaji)

\author{
MUHAMMAD KifAYATULlAH*, HAROON RAHIM, NAEEM UlLAH JAN,
} KAMRAN AHMAD CHISHTI, IRFAN ULLAH \& SUDAIR ABBAS

\begin{abstract}
Pericampylus glaucus is a common Malaysian plant used traditionally in the treatments of joint pain, abdominal pain and headache. Hence, the present research was aimed to evaluate ethanolic extract of Pericampylus glaucus for analgesic, antipyretic and anti-inflammatory activities in experimental animals. The central and peripheral analgesic activity was determined by acetic acid induced writhing and hot plate method by examining the number of writhing and paw licking or jumping time. Meanwhile, the antipyretic activity was determined by Brewer's yeast- test that induced pyrexia and carrageenan-that induced hind paw inflammation was used for anti-inflammatory activities. The ethanolic extract of Pericampylus glaucus at doses (300 and $600 \mathrm{mg} / \mathrm{kg} \mathrm{b.wt)} \mathrm{and} \mathrm{Ibuprofen} \mathrm{(100} \mathrm{mg/kg} \mathrm{(b.wt)} \mathrm{was}$ used as a reference drug in the whole experiment. Intraperitoneal administration of Pericampylus glaucus produced significant $(\mathrm{p}<0.01)$ inhibition in writhing response in acetic acid induced writhing test and dose-dependent $(\mathrm{p}<0.001)$ prolonged paw licking in hot plate test as compared to control (normal saline treated group). Similarly, significant $(\mathrm{p}<0.001)$ attenuation in lowering rectal temperature was noted in animal groups that were treated with ethanolic extract of Pericampylus glaucus at different doses. The attenuation was, almost the same as produced by ibuprofen treated group. Furthermore, Pericampylus glaucus extract also produced significant reduction in hind paw edema $(\mathrm{p}<0.001), 4 \mathrm{~h}$ after administration of carrageenan and inhibition was $60.19 \%$ and $42.17 \%$ as compared to control (normal saline treated group). The findings of this study indicated that Pericampylus glaucus possess significant analgesic, antipyretic and anti-inflammatory activities and could possibly be used in the management of fever, pain and inflammation.
\end{abstract}

Keywords: Analgesic; anti-inflammatory; antipyretic; ethanolic extract; Pericampylus glaucus

\section{ABSTRAK}

Pericampylus glaucus adalah tumbuhan yang biasa digunakan secara tradisi dalam rawatan sakit sendi, sakit badan dan sakit kepala. Oleh yang demikian, penyelidikan ini bertujuan untuk menilai ekstrak etanol Pericampylus glaucus untuk aktiviti analgesik, antipiretik dan anti-radang pada haiwan uji kaji. Aktiviti analgesik pusat dan periferal ditentukan oleh asid asetik bergelut teraruh dan kaedah plat panas dengan memeriksa kadar bergelut dan menjilat tapak kaki atau masa lompatan. Manakala aktiviti antipiretik ditentukan melalui ujian yis Brewer yang mengaruh pireksia dan karaginan - yang mengaruh inflamasi tapak kaki belakang digunakan untuk aktiviti antiradang. Ekstrak etanol Pericampylus glaucus pada dos (300 dan $600 \mathrm{mg} / \mathrm{kg} \mathrm{b.wt)} \mathrm{dan} \mathrm{ibuprofen} \mathrm{(100} \mathrm{mg/kg} \mathrm{b.wt)} \mathrm{telah} \mathrm{digunakan}$ sebagai dadah rujukan pada uji kaji keseluruhan. Pemberian intraperitoneum Pericampylus glaucus menghasilkan perencatan tindak balas bergelut yang signifikan $(\mathrm{p}<0.01)$ dalam ujian bergelut asid asetik dan berkeperluan dos $(\mathrm{p}<0.001)$ menjilat tapak kaki berpanjangan dalam ujian plat panas berbanding kawalan (kumpulan terawat salin normal). Begitu juga, signifikan ( $\mathrm{p}<0.001)$ pelemahan hidrologi merendahkan suhu rektum telah dicatat dalam kelompok haiwan yang telah dirawat dengan ekstrak ethanolic Pericampylus glaucus pada dos yang berbeza. Pengecilan ini hampir sama seperti yang dihasilkan oleh kelompok yang dirawat menggunakan Ibuprofen. Selain itu, ekstrak Pericampylus glaucus juga menghasilkan pengurangan ketara dalam edema di simpul telapak belakang ( $<<0.001)$, 4 jam selepas pemberian carrageenan dan kesan 60.19 dan $42.17 \%$ berbanding kawalan (kelompok salina normal terawat). Keputusan kajian ini menunjukkan bahawa Pericampylus glaucus mempunyai nilai analgesik, antipiretik dan anti-radang yang penting dan mungkin boleh digunakan untuk merawat demam, sakit dan inflamasi.

Kata kunci: Analgesik; anti-radang; antipiretik; ekstrak etanol; Pericampylus glaucus 


\section{INTRODUCTION}

Controlling pain, fever and inflammation is one of the largest challenges for clinical medicines (Ricciotti \& Fitz Gerald 2011). The unpleasant experience, associated with perception of sensation that disrupts a person's life is termed as pain (Ferrell et al. 1991). Inflammatory mediators released in body due to stimulation of mast cell that activate nociceptors (receptor producing pain) and result pain in body (Dray 1995). Furthermore, G proteincoupled receptors are also involved in the development of oedema, inflammation, fever and pain (Ricciotti \& Fitz 2011). Pyrexia is a medical sign primarily associated with increase in body that is then characterised by fatigue, depression, lethargy and anorexia (Kifayatullah \& Waheed 2014). Pro-inflammatory mediators (cytokines) produced by damaging tissues, which enhance the production of prostaglandin E2 (PGE2) (Spacer 1994). Inflammation is a normal response of mammalian tissue in body against invading microorganisms. However, during this response blood cells and plasmic fluid accumulates in the body that leads to edema (Munford \& Pugin 2001). The inflammatory response involves a multigrade initiation of enzymes, release of mediators, leakage of fluid, tissue breakdown and regeneration (Rock \& Kono 2008). The common therapy for controlling fever, pain and inflammation are use of NSAIDs. However, a number of side effects of NSAIDs have been documented with their uses in human being (Hernández-Díaz \& Rodriguez 2000). In order to avoid the side effects natural of product-based new antipyretic, analgesic and anti--inflammatory agents have been endeavoured. Pericampylus glaucus belongs to the family of Menispermaceae, found in Southeast Asian region and is claimed to be effective as traditional medicine for treating various diseases (Kifayatullah et al. 2016). Traditionally, roots of Pericampylus glaucus have been used to lower glucose level, fever and cholesterol level (Ong et al. 2011). Various parts of the plant have been harnessed elsewhere worldwide to stop-bleeding, treat snake bites, swelling, sore throat, joint pain, headache and abdominal pain (Muhammad et al. 2016). In addition, pure compounds such as alkaloids and terpeniods isolated from the plant have been reported for having significant potentials against HBV, cancer and HIV-1 virus (Yan et al. 2008; Zhao \& Cui 2009). The ethanolic extract of Pericampylus glaucus possessed radical scavenger effect in-vitro (Kifayatullah et al. 2015a), besides anti-diabetic and anti-hyperlipidemic effects (Kifayatullah \& Sengupta 2016). The active compound 2-[(trimethylsilyl) oxy] -Methyl Ester (cas) Methyl-o-trimethyl-silylsalicylate from plant has been proven for having hypoglycaemic effects (Kifayatullah et al. 2017). However, to the best of our knowledge, literature review showed that there is no published data until now was reported for the plant regarding the effectiveness of Pericampylus glaucus in the treatment of inflammation, fever and pain. Based on this evidenced, this study was therefore aimed to validate the analgesic, antipyretic and anti-inflammatory activities of Pericampylus glaucus in animal models.

\section{MATERIALS AND METHODS}

\section{DRUGS, CHEMICALS AND INSTRUMENTS}

The standard Ibuprofen of Sigma-Aldrich, was purchased from Bio Syn Tech Malaysia Group. Rotary evaporator model: (N-1000 (EYELA Tokyo Co., LTD.), Japan, Digital thermometer (Holden medical B.V, Netherland) and Hot plate (AREC, VELP Scientific) were used. The other chemicals and reagents used were of analytical grade of Astral Laboratory chemicals and Sigma-Aldrich Co St. Louis, MO 63178 USA. Carrageenan's and Brewer's yeast used were purchased from the local market.

\section{COLLECTION AND IDENTIFICATION OF PLANT MATERIAL}

The plant, Pericampylus glaucus, was collected from Kampung Jeram, Kedah, Negeri Sembilan, Malaysia and authenticated by Ms Tan Ai Lee from the Forest Research Institute Malaysia (FRIM). It was then assigned with herbarium number (FRIM/394/490/5/18(118)). The leaves were washed and dried in shade for a period of three weeks and converted into coarse powder using mechanical grinder.

\section{PREPARATION OF PLANT EXTRACT}

An amount of $100 \mathrm{~g}$ of coarse powder was extracted by continuous hot extraction method using ethanol as solvent in the soxhlet apparatus for a period of $48 \mathrm{~h}$. The collected extract was then concentrated under reduced pressure in rotary evaporator at $40-45^{\circ} \mathrm{C}$ and preserved in desiccator for pharmacological activities.

\section{PRELIMINARY PHYTOCHEMICAL SCREENING}

Previous research from literature review confirmed the presence of various phytochemicals in ethanol extract of Pericampylus glaucus except resin and anthraquione by using Mayer's, Froth, Fehling, Lead acetate, Acetone water and Bontrager's test (Kifayatullah et al. 2015a), before determination of analgesic, antipyretic and antiinflammatory activities.

\section{EXPERIMENTAL ANIMALS}

Male and female Balb/c mice with average weight of 25-30 $\mathrm{g}$ were used in this study and kept in animal holding facility centre of Lincoln University College, Malaysia. The study that involved the use of animal was performed in fulfilment with protocols and the guidelines that were approved by the animal ethics committee of Lincoln University College, Malaysia with Ref No: PHARM/2016/MK/02-Aug/11/Nov 2016-Dec 2016.

\section{ORAL ACUTE TOXICITY STUDY}

OECD 423 guidelines were used for confirming the safety and toxicity of ethanol extract up to $4000 \mathrm{mg} / \mathrm{kg}$ (b.wt) in female Balb/c mice (Kifayatullah et al.2015b). Hence, two 
doses of extract 300 and $600 \mathrm{mg} / \mathrm{kg}$ (b.wt) were chosen in the study and diluted in normal saline before use.

\section{PHARMACOLOGICAL TESTS ANALGESIC ACTIVITY}

The peripheral analgesic effects of ethanol extract of Pericampylus glaucus against acetic acid induced writhing was performed according to the procedure of (Kifayatullah) with some modification (Kifayatullah \& Ishrat 2014). The Balb/c mice were randomly distributed into 4 groups of 5 animals per each cage. Group 1 served as normal control that received only normal saline at dosage of $10 \mathrm{~mL} / \mathrm{kg}$ (b.wt). Group 2 was designated as a positive (standard), received the Ibuprofen at dose of $100 \mathrm{mg} / \mathrm{kg}$ (b.wt) intraperitonealy (i.p) while group 3 group and 4 were given ethanolic extract at dose 300 and $600 \mathrm{mg} / \mathrm{kg}$ (b.wt), respectively, and were designated as test group. For induction of pain $1 \mathrm{~h}$ after treatment, a volume of $0.2 \mathrm{~mL}$ of $0.6 \% \mathrm{v} / \mathrm{v}$ of acetic acid solution was injected intraperitonealy to all animals group and the total number of writhing was counted for duration of 20 min just 05 min after intraperitoneal (i.p) administration of acetic acid solution. The number of writhing in all treated group was compared to normal group (untreated group). The $\%$ of inhibition of writhing for all treated group was determined from the mean writhing count of normal control group by following equation (Kifayatullah \& Ishrat 2014).

$$
\% \text { age of inhibition }=\frac{\mathrm{Nc}-\mathrm{Nt}}{\mathrm{Nc}} \times 100
$$

where $\mathrm{Nc}$ is the average number of writhing of normal control (normal saline) per group; and Nt is the average number of writhing of test per group (extract and standard). The same procedure of grouping was applied for determining the central analgesic activity of ethanol extract of Pericampylus glaucus by placing each animal on hot metal plate maintained at $55^{\circ} \mathrm{C}$ to measure the latency time (Kifayatullah \& Ishrat 2014). Group 1 served as normal control received only normal saline at dosage of $10 \mathrm{~mL} /$ $\mathrm{kg}$ (b.wt). Group 2 was kept as positive control (standard) treated with Ibuprofen at dose of $100 \mathrm{mg} / \mathrm{kg}$ (b.wt). Group 3 and 4 were designated as test groups for ethanolic extract, were treated i.p at dose rate of 300 and $600 \mathrm{mg} / \mathrm{kg}$ (b.wt), respectively. The time between placement and shaking or licking of the paws or jumping was recorded as the index of response latency. The response of latency for each animal group used in this study was noted down in hot plate for $3 \mathrm{~h}$ and the interval was thirty min followed with cut off time $15 \mathrm{~s}$ in order to prevent damage of tissue.

\section{ANTIPYRETIC ACTIVITY}

The antipyretic effect of ethanol extract of Pericampylus glaucus was evaluated based on Brewer's yeast induced pyrexia test (Kifayatullah \& Waheed 2014). Healthy Balb/c mice of both sexes with average weight (25-30 g) were used in this study that was randomized into 4 groups of 5 animals each. Digital thermometer was used to record the rectal body temperature. Subcutaneous injection of yeast $(20 \% \mathrm{w} / \mathrm{v})$ diluted in normal saline was used for induction of pyrexia. The rectal temperature was recorded $17 \mathrm{~h}$ after subcutaneous (s/c) injection. Group 1 served as a normal control, received only normal saline at dose $10 \mathrm{~mL} / \mathrm{kg}$ (b.wt), group 2 was kept as positive (standard), treated with yeast and Ibuprofen at $100 \mathrm{mg} / \mathrm{kg}$ (b.wt) intraperitonealy (i.p). Group 3 and 4 were administered intraperitoneal (i.p) with yeast and extract at 300 and $600 \mathrm{mg} / \mathrm{kg}$ (b.wt), respectively. The rectal temperatures of each group were recorded at $0,1,2,3$ and $4 \mathrm{~h}$ after administration of ethanolic extract and Ibuprofen.

\section{ANTI-INFLAMMATORY ACTIVITY}

Carrageenan-induced inflammation on the hind paw method was used to evaluate the anti-inflammatory action of ethanolic extract of Pericampylus glaucus that was explained earlier with some changes in procedure (Brahmbhatt et al. 2010). Balb/c mice (male and female) after an overnight fasting except free excess to water was distributed into 4 groups of 5 animals per cage. All the animals were injected with $0.1 \mathrm{~mL}$ of freshly prepared $1 \%$ $(\mathrm{w} / \mathrm{v})$ carrageenan on the sub plantar right hind paw of each mouse for induction of oedema. Group 1 served as normal control. Normal saline at dose of $10 \mathrm{~mL} / \mathrm{kg}$ (b.wt) was given to 1 group and served as normal control. Group 2 was treated with Ibuprofen at dosage of $100 \mathrm{mg} / \mathrm{kg}$ (b.wt) and served as positive control. Group 3 and 4 were treated i.p with ethanolic extract of Pericampylus glaucus at dosage of 300 and $600 \mathrm{mg} / \mathrm{kg}$ (b.wt), respectively. Treatments with Ibuprofen and extract were performed $60 \mathrm{~min}$ before administration of carrageenan. Increase in paw thickness was measured with vernier caliper just before and after 1 , 2,3 , and $4 \mathrm{~h}$ of carrageenan injection. The percentage of inhibition was calculated with respect to its vehicle- treated group (normal saline) by formula:

$$
\text { Inhibition }(\%)=\frac{\begin{array}{l}
\text { Means oedema } \text { control }- \text { means oedema } \\
\text { Mean paw oedema of control }
\end{array}}{\text { of sample }} \times 100
$$

\section{STATISTICAL ANALYSIS}

Values were expressed as mean \pm Standard Error of Means (SEM). Values were statistically analysed by two-way analysis of variance (ANOVA) followed by Bonferroni test. Probability $(p)$ levels of $p<0.05, p<0.01$ and $p<0.001$ were considered statistically significant.

\section{RESULTS}

\section{PRELIMINARY PHYTOCHEMICAL SCREENING}

The presence of various phytochemicals in the ethanol extract of Pericampylus glaucus showed the existence of saponins, alkaloids, reducing sugars, flavonoids, tannins, 
sterol, terpeniods except anthraquionones and resin. The results are summarized in Table 1.

TABLE 1. Phytochemical analysis of ethanolic extract of Pericampylus glaucus

\begin{tabular}{ccc}
\hline \multicolumn{3}{c}{ Phytochemical Test performed Result } \\
\hline Alkaloids & Mayer's & Present \\
Tannins & Lead acetate & Present \\
Saponins & Froth & Present \\
Flavonoid & Alkaline reagent & Present \\
Anthraquione & Liebermann & Absent \\
Sterol & Fehling Acetone & Present \\
Resin & Acetone & Absent \\
\hline
\end{tabular}

\section{ANALGESIC ACTIVITY}

The effects of ethanol extract of Pericampylus glaucus and Ibuprofen on acetic acid induced writhing in Balb/c mice are summarized in Table 2 . The result indicated that mice pre-treated with 300 and $600 \mathrm{mg} / \mathrm{kg}$ (b.wt) of extract produced significant reduction in writhing $(p<0.001)$ as compared to normal control. The inhibition percentage was $30.28 \%$ and $55.67 \%$ for ethanol extract at 300 and $600 \mathrm{mg} / \mathrm{kg}$ (b.wt), respectively. The positive control group treated with Ibuprofen at $100 \mathrm{mg} / \mathrm{kg}$ (b.wt) produced more potent inhibition $(71.02 \%, p<0.001)$ in writing response than ethanolic extract.

TABLE 2. Analgesic effects of Pericampylus glaucus and Ibuprofen in acetic acid-induced writhing in Balb $\mathrm{C}$ mice

\begin{tabular}{ccc}
\hline Treatment & Count $/$ min & $\begin{array}{c}\text { Inhibition of } \\
\text { writhing }(\%)\end{array}$ \\
\hline Normal Control & $42.10 \pm 1.11$ & 71.02 \\
Ibuprofen $100 \mathrm{mg} / \mathrm{kg}$ (b.wt) & $12.20 \pm 0.36^{\mathrm{c}}$ & 30.28 \\
$300 \mathrm{mg} / \mathrm{kg}$ (b.wt) & $29.35 \pm 0.71^{\mathrm{b}}$ & 55.67 \\
$600 \mathrm{mg} / \mathrm{kg}$ (b.wt) & $18.66 \pm 0.80^{\mathrm{c}}$ & \\
\hline
\end{tabular}

Data are expressed as mean $\pm \mathrm{SEM}, n=5,{ }^{\mathrm{b}} p<0.01,{ }^{\mathrm{c}} p<0.001$ significant in relative to control

Treatment with ethanolic extract of Pericampylus glaucus at 300 and $600 \mathrm{mg} / \mathrm{kg}$ (b.wt) significantly $(p<0.001)$ prolonged the latency time as compared to negative control (normal saline treated group). The significant effects began as early as $30 \mathrm{~min}$ and last for 150 min. The increase in latency time was dose-dependent and the maximum effect was found at $150 \mathrm{~min}$ with latency time for $300 \mathrm{mg} / \mathrm{kg}$ (b.wt) was $38.95 \pm 0.01$ while for 600 $\mathrm{mg} / \mathrm{kg}$ (b.wt), the latency time was $44.70 \pm 1.34$. After 150 min, the latency time began to decline for both dosages of ethanolic extract. The latency time for Ibuprofen was also the highest at $150 \mathrm{~min}(53.66 \pm 0.18)$ and then declined. The results are summarized in Table 3 .

\section{ANTIPYRETIC ACTIVITY}

Treatment of Balb/c mice with ethanol extract displayed dose-dependent antipyretic effect against brewer's yeast induced pyrexia was shown by reduction in rectal temperature. The initial average rectal temperature of animals group was $34.7^{\circ} \mathrm{C}$. The ethanol extract caused lowering of the body temperature up to $4 \mathrm{~h}$ following its administration. A significant incremental change in rectal temperature was noted after subcutaneous $(\mathrm{s} / \mathrm{c})$ injection of yeast peaking at about $17 \mathrm{~h}$ that was $38.10^{\circ} \mathrm{C}$ that was further decrease to $37.0^{\circ} \mathrm{C} 1 \mathrm{~h}$ after treatment with ethanolic extract at $600 \mathrm{mg} / \mathrm{kg}$ (b.wt) and subside after 4 $\mathrm{h}$ showing a sizeable reduction in rectal temperature that was almost same as showed by Ibuprofen. The ethanolic extract at $300 \mathrm{mg} / \mathrm{kg}$ (b.wt) produced attenuation in fever but was not statistically $(p>0.05)$ significant up to $2 \mathrm{~h}$ and showed slight significant $(p<0.05)$ after $3 \mathrm{~h}$ that become $p<0.01)$ after $4 \mathrm{~h}$ of treatment as compared to control group (normal saline). Treatment with Ibuprofen at dose rate $100 \mathrm{mg} / \mathrm{kg}$ (b.wt) significantly $(p<0.001)$ reduced rectal temperature that was induced by yeast $3 \mathrm{~h}$ after administration. Attenuation in rectal temperature after treatment with ethanolic extract at 300 and $600 \mathrm{mg} / \mathrm{kg}$ (b.wt) was nearly equally potent to Ibuprofen. The results are tabulated in Table 4

\section{ANTI-INFLAMMATORY ACTIVITY}

Intraperitoneal administration of ethanol extract of Pericampylus glaucus produced significant dosedependent reduction in hind paw edema induced by injection of carrageenan. After 3 and $4 \mathrm{~h}$ of carrageenan induction, ethanolic extract at 300 and $600 \mathrm{mg} / \mathrm{kg}$ (b.w) showed significant anti-inflammatory activity $(p<0.001)$ as compared to control. The carrageenan-induced paw edema significantly reduced by $54.36 \%$ and $60.19 \%$, respectively, at $4 \mathrm{~h}$ of treatment as compared to that of control group. Inhibition of edema by Ibuprofen at 100

TABLE 3. Analgesic effects of ethanolic Pericampylus glaucus extract of in Eddy Hot plate mouse model

\begin{tabular}{cccccccc}
\hline Treatment & $0 \mathrm{~min}$ & $30 \mathrm{~min}$ & $60 \mathrm{~min}$ & $90 \mathrm{~min}$ & $120 \mathrm{~min}$ & $150 \mathrm{~min}$ & $180 \mathrm{~min}$ \\
\hline Control (Normal saline) & $8.1 \pm 1.1$ & $7.1 \pm 1.2$ & $9.1 \pm 0.01$ & $8.3 \pm 1.0$ & $9.5 \pm 1.8$ & $10.70 \pm 0.8$ & $7.5 \pm 1.3$ \\
Ibuprofen $100 \mathrm{mg} / \mathrm{kg}$ (b.wt) & $9.2 \pm 1.1$ & $24.4 \pm 1.39$ & $30.2 \pm 2.2$ & $37.9 \pm 1.2$ & $46.0 \pm 1.7$ & $53.6 \pm 0.1^{\mathrm{c}}$ & $49.7 \pm 1.4$ \\
$300 \mathrm{mg} / \mathrm{kg}$ (b.wt) & $10.2 \pm 0.9$ & $17.0 \pm 1.7^{\mathrm{a}}$ & $23.3 \pm 1.2^{\mathrm{b}}$ & $28.3 \pm 1.4^{\mathrm{b}}$ & $34.5 \pm 1.0^{\mathrm{c}}$ & $38.9 \pm 0.01^{\mathrm{c}}$ & $33.2 \pm 0.1^{\mathrm{c}}$ \\
$600 \mathrm{mg} / \mathrm{kg}$ (b.wt) & $10.6 \pm 2.0$ & $21.3 \pm 1.8^{\mathrm{b}}$ & $29.3 \pm 1.2^{\mathrm{b}}$ & $32.1 \pm 1.9^{\mathrm{c}}$ & $37.2 \pm 1.5^{\mathrm{c}}$ & $44.7 \pm 1.3^{\mathrm{c}}$ & $39.3 \pm 1.5^{\mathrm{c}}$ \\
\hline
\end{tabular}

Data are expressed as mean $\pm \mathrm{SEM}, n=05,{ }^{\mathrm{a}} p<0.05,{ }^{\mathrm{b}} p<0.01,{ }^{\mathrm{c}} p<0.001$, significant as matched to normal control 
TABLE 4. Antipyretic activity of Pericampylus glaucus by Brewer's yeast induced pyrexia

\begin{tabular}{cccccccc}
\hline Treatment & \multicolumn{6}{c}{ Rectal temperature in ${ }^{\circ} \mathrm{C}$ after $17 \mathrm{~h}$ of s/c injection of Brewer's yeast } \\
\hline Normal & Normal & After $17 \mathrm{~h}$ & $0 \mathrm{~h}$ & $1 \mathrm{~h}$ & $2 \mathrm{~h}$ & $3 \mathrm{~h}$ & $4 \mathrm{~h}$ \\
\cline { 2 - 8 } & $34.7 \pm 0.1$ & $37.9 \pm 0.1$ & $37.7 \pm 0.1$ & $37.6 \pm 0.1$ & $37.4 \pm 0.1$ & $37.2 \pm 0.1$ & $37.1 \pm 0.4$ \\
\hline Ibuprofen $100 \mathrm{mg} / \mathrm{kg}$ (b.wt) & $35.7 \pm 0.2$ & $37.9 \pm 0.1$ & $37.9 \pm 0.4$ & $37.5 \pm 0.1$ & $36.6 \pm 0.7$ & $36.2 \pm 0.36$ & $35.4 \pm 0.2^{\mathrm{c}}$ \\
$300 \mathrm{mg} / \mathrm{kg}$ (b.wt) & $35.5 \pm 0.2$ & $37.8 \pm 0.9$ & $37.6 \pm 0.5$ & $37.2 \pm 0.7$ & $36.9 \pm 0.3$ & $36.6 \pm 0.145^{\mathrm{a}}$ & $36.3 \pm 0.4^{\mathrm{b}}$ \\
$600 \mathrm{mg} / \mathrm{kg}$ (b.wt) & $35.8 \pm 0.8$ & $38.1 \pm 0.6$ & $37.7 \pm 0.7$ & $37.3 \pm 0.0$ & $36.5 \pm 0.9$ & $36.3 \pm 0.7^{\mathrm{c}}$ & $35.7 \pm 0.6^{\mathrm{c}}$ \\
\hline
\end{tabular}

Values are expressed as mean $\pm \mathrm{SEM}, n=5,{ }^{\mathrm{a}} p<0.05,{ }^{\mathrm{b}} p<0.01,{ }^{\mathrm{c}} p<0.001$, significant as matched to control

$\mathrm{mg} / \mathrm{kg}$ (b.wt) was $73 \%$. The results are summarised in Table 5 .

\section{DISCUSSION}

The present research aimed to investigate analgesic, antipyretic and anti-inflammatory effects of ethanol extract of Pericampylus glaucus in mice. Preliminary phytochemical screening on Pericampylus glaucus showed the presence of alkaloids, tannins, saponins, flavonoid except anthraquione and resin. Preliminary oral acute toxicity assessment of the ethanolic leaf extract Pericampylus glaucus in female Balb/c mice showed no mortality after 14 days of examination suggesting that the lethal dose (LD 50) of the extract is above $4000 \mathrm{mg} /$ $\mathrm{kg}$ (b.wt). The ethanol extract of Pericampylus glaucus leaves was evaluated for analgesic effect against acetic acid-induced visceral pain and further supported by Eddy hot-plate test. Pain sensation was generated by intraperitoneal injection of acetic acid that caused contraction of abdominal muscle followed by extension of hind limbs and elongation of body part, which is mediated by local peritoneal receptor (Subedi et al. 2016). The acetic acid-induced writhing is a common technique used for screening of peripheral analgesic activity for plant-based drugs (Zulfiker et al. 2010). Administration of acetic acid causes release of endogenous substances that are supposed to excite the nerve endings and then results in pain (Subedi et al. 2016). The major contribution of prostaglandins to evoke pain response is mainly due to interaction with endogenous mediators that are responsible to stimulate sensitization of pain receptors (Gold \& Gebhart 2010). The ethanol extract of Pericampylus glaucus at different doses was able to reduce writhing response significantly and this was possibly mediated through prostaglandins inhibition mechanism. Prolonged reaction time of jumping with ethanol extract of Pericampylus glaucus was observed during all experimental observations indicating that extract might be acting spinally that might be explored additionally. However, it has been confirmed from previous studies that activation of $\mu 2$ opioid subtype receptor caused the formation of spinal analgesia (Bhowmick et al. 2014). Hence, it could be assumed that the central analgesic effects of Pericampylus glaucus extract is possibly to be mediated centrally. It is suggested that the ethanol extract exhibited central analgesic effects as proven by findings in the Eddy hot-plate method. Proteins present in Brewer's yeast are mainly linked to the developments of fever due to production of inflammatory cytokines in inflammatory reactions (Horai et al. 1998). Antipyretics such as Ibuprofen used in the management of fever decrease the levels of prostaglandins hence antipyretic messages in the brain (Aronoff \& Neilson 2001). Giving similar results observed between the use of Ibuprofen and ethanolic extract, it is therefore, believed that antipyretic properties of ethanol extract is mostly mediated through interference of prostaglandin synthesis and inhibition of cytokines release. Various studies confirmed that plant-based drugs showing analgesic potentials also possess antipyretic effect in addition to anti-inflammatory activities (Kifayatullah et al. 2017), which are manifested by suppression of fever, pain and inflammation as a result of inhibition of inflammatory mediators. The plant-based biological benefits such as analgesic, antipyretic and anti-inflammatory potentials are mediated by secondary metabolites. Carrageenan-induced hind paw edema model is widely used to evaluate anti-inflammatory and anti-oedema effects of plant-based compounds. Development of edema after injection of carrageenan

TABLE 5. Effect of ethanolic extract of Pericampylus glaucus on inhibition of edema induced by carrageenan

\begin{tabular}{ccccc}
\hline & \multicolumn{5}{c}{ Inhibition (\%) } \\
\hline Treatment & $1 \mathrm{~h}$ & $2 \mathrm{~h}$ & $3 \mathrm{~h}$ & $4 \mathrm{~h}$ \\
Normal & 0 & 0 & 0 & 0 \\
Ibuprofen $100 \mathrm{mg} / \mathrm{kg}$ (b.wt) & $28.43 \%$ & $47.61 \%$ & $62.5 \%$ & $73 \%$ \\
$300 \mathrm{mg} / \mathrm{kg}$ (b.wt) & $12.75 \%$ & $29.52 \%$ & $34 \%$ & $54.36 \%$ \\
$600 \mathrm{mg} / \mathrm{kg}$ (b.wt) & $8.82 \%$ & $31.42 \%$ & $44.64 \%$ & $60.19 \%$ \\
\hline
\end{tabular}


occurs in two stages involving cyclooxygenases that last for $6 \mathrm{~h}$ (Halici et al. 2007). The first phase occurred within the first $2 \mathrm{~h}$ that is related to the release of bradykinin, serotonin and histamine by inflamed tissues whereas the second phase is mainly caused by the release of free radicals and prostaglandin by neutrophils that take place 3-5 h post injection of carrageenan (Ben Khedir et al. 2016). Reduction of hind paw oedema in a dosedependent manner suggests that ethanol extract may inhibit prostaglandin formation. In brain, cyclooxygenase (COX)-2 is responsible to mediate prostaglandin synthesis that causes peripheral inflammation which then contributes to hyperalgesia and allodynia. In mast cells, prostaglandin D2, prostaglandin F2 $\alpha$ and prostaglandin E2 are metabolites of cyclooxygenase pathway that increase vascular permeability and vasodilatation hence edema (Hétu \& Riendeau 2005). The inhibitory effect of ethanol extract on carrageenan-induced inflammation may therefore be due to the inhibition of cyclooxygenase and prostaglandin synthesis. Natural compounds such as flavonoids inhibit synthesis of prostaglandins in the late phase of inflammation (Rathee et al. 2009). Thus, the presence of flavonoids in the extract might suppress the formation of prostaglandins and bradykinin that contribute to anti-inflammatory effects.

\section{CONCLUSION}

The present study confirmed the analgesic, antipyretic and anti-inflammatory activities of ethanolic extract of Pericampylus glaucus used by local community against pain, fever and inflammation. However, further research is needed to establish the mechanisms involved in these effects and also to isolate active natural compounds responsible for the mentioned activities.

\section{ACKNOWLEDGEMENTS}

The authors are thankful to the Department of Pharmacy, Faculty of Life Sciences, Sarhad University of Science and Information Technology, Peshawar for providing financial support for publishing this research.

\section{REFERENCES}

Aronoff, D.M. \& Neilson, E.G. 2001. Antipyretics: Mechanisms of action and clinical use in fever suppression. American Journal of Medicine 4: 304-315.

Ben Khedir, B.S., Mzid, M., Bardaa, S., Moalla, D., Sahnoun, Z. \& Rebai, T. 2016. In vivo evaluation of the anti-inflammatory effect of Pistacia lentiscus fruit oil and its effects on oxidative stress. Evidence-Based Complementary and Alternative Medicine 2016: 6108203.

Brahmbhatt, M., Patel, J., Patel, V. \& Saluja, S. 2010. Analgesic and anti-inflammatory activity of leaves of Rivea hypocrateriformis. Journal of Pharmacognosy and Phytotherapy 1: 001-003.

Bhowmick, R., Sarwar, M.S., RahmanDewan, S.M., Das, A., Das, B., NasirUddin, M.M. \& Islam, M.S. 2014. In vivo analgesic, antipyretic, and anti-inflammatory potential in Swiss albino mice and in vitro thrombolytic activity of hydroalcoholic extract from Litsea glutinosa leaves. Biological Research 47: 47-56.

Dray, A. 1995. Inflammatory mediators of pain. British Journal of Anaesthesia 75: 125-131.

Ferrell, B., Grant, M., Padilla, G., Vemuri, S. \& Rhiner, M. 1991. The experience of pain and perceptions of quality of life: Validation of a conceptual model. American Heart Hospital Journal 3: 9-24.

Gold, M.S. \& Gebhart, G.F. 2010. Nociceptor sensitization in pain pathogenesis. Nature Medicine 11: 1248-1257.

Halici, Z., Dengiz, G.O., Odabasogl, F., Suleyman, H., Cadirci, E. \& Halici, M. 2007. Amiodarone has anti-inflammatory and anti-oxidative properties: An experimental study in rats with carrageenan-induced paw edema. European Journal of Pharmaceutical Sciences 566: 215-221.

Hernández-Díaz, S. \& Rodríguez, L.A.G. 2000. Association between nonsteroidal anti-inflammatory drugs and upper gastrointestinal tract bleeding/perforation: An overview of epidemiologic studies published in the 1990s. JAMA Internal Medicine 14: 2093-2099.

Hétu, P.O. \& Riendeau, D. 2005. Cyclo-oxygenase-2 contributes to constitutive prostanoid production in rat kidney and brain. Biochemical Journal 3: 561-566.

Horai, R., Asano, M., Sudo, K., Kanuka, H., Suzuki, M. \& Nishihara. 1998. Production of mice deficient in genes for interleukin (IL)- $1 \alpha$, IL-1 $\beta$, IL- $1 \alpha / \beta$, and IL-1 receptor antagonist shows that IL- $1 \beta$ is crucial in turpentine-induced fever development and glucocorticoid secretion. Journal of Experimental Medicine 9: 1463-1475.

Kifayatullah, M. \& Sengupta, P. 2016. Effect of Pericampylus glaucus on plasma glucose concentration and lipid profile in streptozotocin-induced diabetic rats. Bangladesh Journal of Pharmacology 11: 200-205.

Kifayatullah, M. \& Ishrat, W. 2014. Evaluation of hydroethanolic extract of Opuntia monacantha Haw. for analgesic activity. World Journal of Pharmaceutical Sciences 2: 1006-1020.

Kifayatullah, M. \& Waheed, I. 2014. Evaluation of hydroethanolic extract of Opuntia monacantha Haw cladodes for antipyretic activity. World Journal of Pharmaceutical Sciences 3: 10211030.

Kifayatullah, M., Mustapha, M.S., Sarker, M.M.R. \& Amin, M. 2017. Effect of compounds identified in the active fraction of Pericampylus glaucus on blood glucose and lipid profiles in streptozotocin-induced diabetic rats. Egyptian Pharmaceutical Journal 16: 8-15.

Kifayatullah, M., Sarker, M.M.R. \& Mustaph, M.S. 2016. Phytochemical investigation of ethanolic extract of Pericampylus glaucus leaves from Malaysia by GC-MS analytical technique. International Journal PharmTech Research 12: 410-416.

Kifayatullah, M., Senguptha, P., Mustafa, M.S., Das, S.K. \& Sisugoswomi, M. 2015a. Evaluation of ethanolic extract of Pericampylus glaucus (Lamk.) Merr for total phenolic, total flavonoids contents and in vitro anti-oxidant activity. International Journal of Pharmacognosy and Phytochemical Research 7: 677-683.

Kifayatullah, M., Mustafa, M.S., Sengupta, P., Sarker, M.M.R., Das, A. \& Das, S.K. 2015b. Evaluation of the acute and sub-acute toxicity of the ethanolic extract of Pericampylus glaucus (Lam.) Merr. in BALB/c mice. Journal of Acute Disease 4: 309-315. 
Muhammad, K., Mohd, S., Muhammad, A., Sardar, H. \& Izhar, U. 2016. A review on Malaysian medicinal plants having anti-hyperglycemic activity. Journal of Coastal Life Medicine 4: 898-901.

Munford, R.S. \& Pugin, J. 2001. Normal responses to injury prevent systemic inflammation and can be immunosuppressive. Am. J. Respir. Crit. Care Med. 2: 316-321.

Ong, H., Chua, S. \& Milow, P. 2011. Ethno-medicinal plants used by the Temuan villagers in Kampung Jeram Kedah, Negeri Sembilan, Malaysia. Studies on Ethno-Medicine 5: 95-100.

Rathee, P., Chaudhary, H., Rathee, S., Rathee, D., Kumar, V. \& Kohli, K. 2009. Mechanism of action of flavonoids as anti-inflammatory agents: A review. Current Drug TargetsInflammation \& Allergy 8: 229-235.

Ricciotti, E. \& FitzGerald, G.A. 2011. Prostaglandins and inflammation. Arteriosclerosis, Thrombosis, and Vascular Biology 5: 986-1000.

Rock, K.L. \& Kono, H. 2008. The inflammatory response to cell death. Annual Review of Pathology: Mechanisms of Disease 3: 99-126.

Spacer, C.B. \& Breder, C.D. 1994. The neurologic basics of fever. New England Journal of Medicine 330: 1880-1886.

Subedi, N.K., Rahman, S. \& Akbar, M.A. 2016. Analgesic and antipyretic activities of methanol extract and its fraction from the root of Schoenoplectus grossus. Evidence-Based Complementary and Alternative Medicine 12: 1-8.
Yan, M.H., Cheng, P., Jiang, Z.Y., Ma, Y.B., Zhang, X.M., Zhang, F.X., Yang, L.M., Zheng, Y.T. \& Chen, J.J. 2008. Periglaucines A-D, anti-HBV and-HIV-1 alkaloids from Pericampylus glaucus. Journal of Natural Products 5: 760-763.

Zhao, W. \& Cui, C. 2009. Triterpenoidal constituents of Pericampylus glaucus and their antitumor activity in vitro. Chinese Journal of Chemistry 19: 195-199.

Zulfiker, A., Rahman, M.M., Hossain, M.K., Hamid, K., Mazumder, M. \& Rana, M.S. 2010. In vivo analgesic activity of ethanolic extracts of two medicinal plants-Scoparia dulcis L. and Ficus racemosa Linn. Biology and Medicine 2: 42-48.

Department of Pharmacy

Faculty of Life Sciences

Sarhad University of Science and Information Technology,

Peshawar

Pakistan

*Corresponding author; email: kifayatpharma86@yahoo.com

Received: 7 July 2018

Accepted: 29 November 2018 